7. Reprod. Fert. (1970) 22, 371-373

\title{
ALKALINE PHOSPHATASE IN THE CYTOPLASMIC DROPLET OF RABBIT SPERMATOZOA
}

\author{
S. BAVDEK* AND T. D. GLOVER \\ Unit of Reproductive Biology, University of Liverpool
}

(Received 1st January 1970)

The presence of acid and alkaline phosphatase has been demonstrated biochemically in bull spermatozoa (Roussel \& Stallcup, 1966), and lysosomal acid phosphatases have been shown to occur in the cytoplasmic droplet of bull and ram spermatozoa (Dott \& Dingle, 1968). Both types of phosphatases have also been shown histochemically in the spermatozoa of bulls (Krause, 1969) and several other mammalian species (Wislocki, 1949; Bern, 1949). Allison \& Hartree (1969) have referred to acid phosphatase being concentrated in the acrosome of vertebrate and invertebrate spermatozoa but there appears to be no comprehensive information about the localization of alkaline phosphatase in spermatozoa. The present paper reports on such a localization in rabbit epidiymal spermatozoa.

During an investigation into the histochemistry of the rabbit epididymis, it was noticed that the cytoplasmic droplets of epididymal spermatozoa reacted positively when stained with Gomori's method, using sodium- $\beta$-glyceryl-phosphate as the substrate. The reaction depended upon the $\mathrm{pH}$ being strongly alkaline (preferably $9 \cdot 6$ ), and it was totally inhibited by the addition of cysteine (4 to $8 \mathrm{~mm}$ ) to the substrate. The cytoplasmic droplets of testicular spermatozoa were also seen to react to staining with alkaline phosphatase (Plate la), but subjectively, proximal and migrating droplets did not appear to react as strongly as spermatozoa from the cauda epididymidis (Plate 1b), where, typically, the droplet has reached the end of the mid-piece and taken up an eccentric position on the flagellum.

Alkaline phosphatase not only occurs in spermatozoa from intact epididymides but also in those from a ligated epididymis. After 14 days of epididymal ligation, many spermatozoa in the ductuli efferentes possess cytoplasmic droplets that have already migrated to the end of the mid-piece, even though they are often distorted when conventionally stained (Gaddum \& Glover, 1965). The present work has shown that these droplets also have considerable alkaline phosphatase activity.

It is of interest that in rabbit spermatozoa, alkaline phosphatase is concentrated exclusively in the cytoplasmic droplet, since it detracts from any categorical assertion that the droplet is entirely inert. Combine with this the membranous nature of cytoplasmic droplets, and the possibility of some local transport mechanism emerges (Morgan, Post \& Park, 1960; Coleman \& Finean, 1968).

* Present address : Biotechnical Faculty, University of Ljubljana, Yugoslavia. 
It is possible, of course, that the enzyme could simply be left over from the original spermatid cytoplasm but there is evidence that, in other areas of the male genital tract, alkaline phosphatase is associated with the transport of sugars across membranes (Bern, 1949; Mann, 1964), and the possibility of it being active in the cytoplasmic droplet should not be discounted. Since there is an abundance of alkaline phosphatase activity in the epididymal epithelium (Bern, 1949; Nicander, 1957a, b; Linnetz \& Amman, 1968) and in the cytoplasmic droplets, it would be attractive to propose that the cytoplasmic droplets might in some way utilize the glycogen which is also present in the epithelium (Nicander, 1954) for the benefit of contained spermatozoa. All this must remain speculative until new evidence is available, but it would seem worth-while paying some attention to this rather curious occurrence of enzyme activity.

The present result may seem surprising in view of the report by Stambaugh \& Buckley (1969) that they were unable to demonstrate phosphatases quantitatively in rabbit spermatozoa. It might be that the content in the droplet is too small to give a reading with the method used by these workers. Alternatively, differences in substrate might be involved for it is noteworthy that o-carboxyphenylphosphate used by these workers for both acid and alkaline phosphatase determinations differed from the substrate used in the present work and also from that employed by Dott \& Dingle (1968).

Experiments are now being planned to examine the occurrence of alkaline phosphatase in degenerating epididymal spermatozoa and to test the effects of ejaculation frequency on the reaction. It might also be valuable to examine the distribution of alkaline phosphatase in ejaculated spermatozoa, provided a satisfactory technique for demonstrating it could be devised. It is important to know, too, whether this strict localization of alkaline phosphatase in cytoplasmic droplets is widespread among epididymal spermatozoa of mammals, or whether it is only characteristic of certain species.

\section{REFERENCES}

Allison, A. G. \& HartreE, E. F. (1969) Lysosomal nature of the acrosomes of ram spermatozoa., Biochem. 7. 3, 35 .

BERN, H. A. (1949) The distribution of alkaline phosphatase in the genital tract of male mammals. Anat. Rec. 104, 361 .

Colmman, R. \& Finean, J. B. (1968) The cell surface membrane. In: Comprehensive Biochemistry, Vol. 23 p. 99. Eds. M. Florkin and E. H. Stobz.

Dotт, H. M. \& Dingle, J. T. (1968) Distribution of lysosomal enzymes in the spermatozoa and cytoplasmic droplets of bull and ram. Expl Cell Res. 52, 523.

Gaddum, P. \& Glover, T. D. (1965) Some reactions of rabbit spermatozoa to ligation of the epididymis. 7. Reprod. Fert. 9, 11.

KRAuse, D. (1969) The role of semen examination in assessing the fertility of bulls. In: The Blue Book for the Veterinary Profession. Hoechst, Hanover.

Linnetz, L. J. \& Amann, R. P. (1968) The male rabbit. II. Histochemistry of the epididymis and ampulla as influenced by sperm output. F. Reprod. Fert. 16, 343.

ManN, Т. (1964) Biochemistry of semen and of the male reproductive tract. Methuen, London.

Morgan, H. E., Post, R. L. \& PARK, G. R. (1960) Glucose transport and phosphorylation in the perfused heart of normal and diabetic rats. In: Membrane Transport and Metabolism, p. 423. Eds. K. Kleinzeller and A. Kotyk. Academic Press, New York and London (C) Nakledatelstr Ceskoslovenski akademie ved Praha.

Nicander, L. (1954) Glycogen secretion in the epididymis. Nature, Lond. 174, 700.

NICANDER, L. (1957a) On the regional histology and cytochemistry of the ductus epididymidis in rabbits. Acta morph. neerl.-scand. 1, 98. 


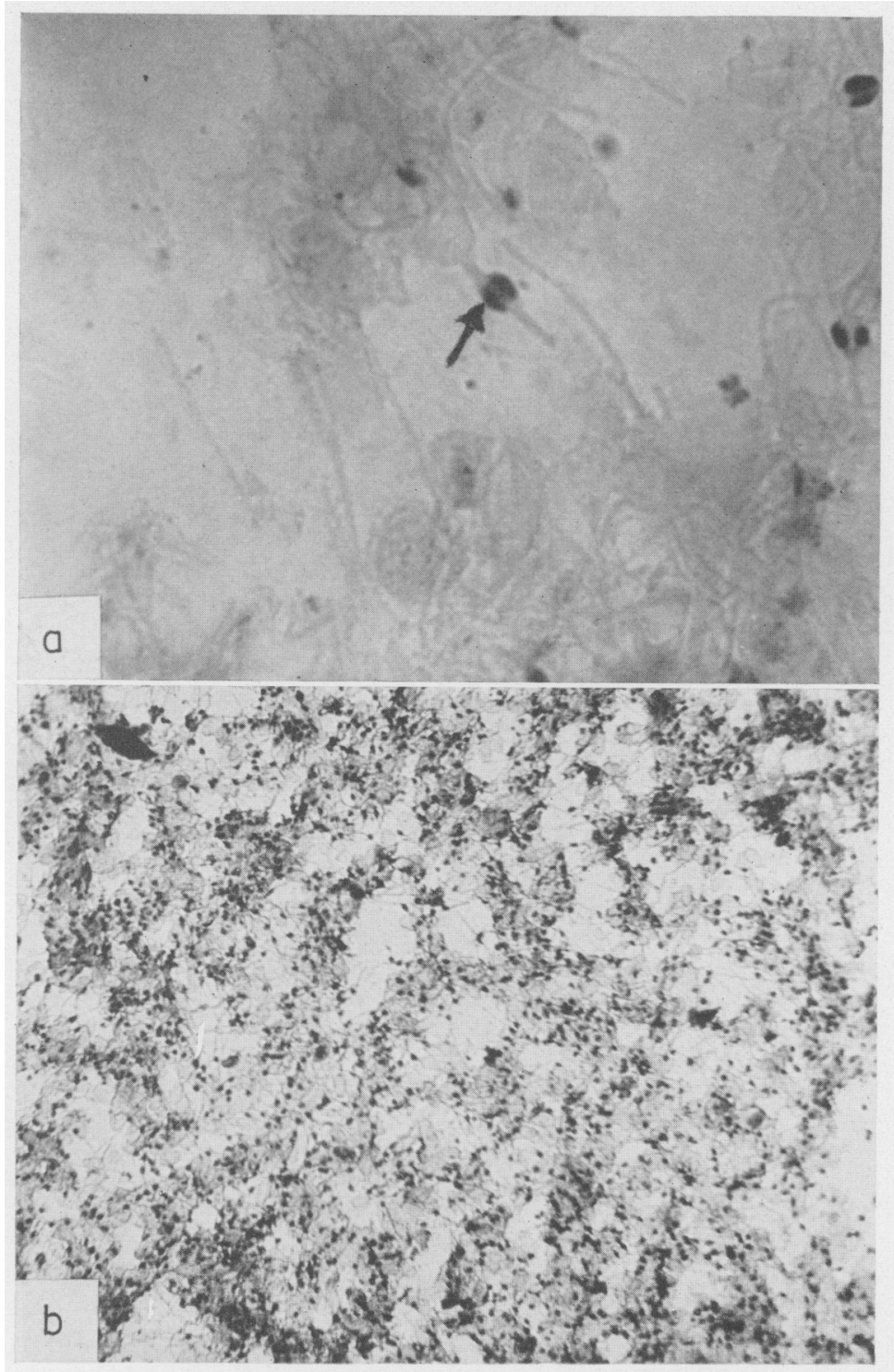

FIg. a. Spermatozoa from the testis and ductuli efferentes of the rabbit showing alkaline phosphatase reaction confined to the cytoplasmic droplet. $\times 1500$.

Fig. b. Spermatozoa taken from the tail of the epididymis of the rabbit showing a mass of cytoplasmic droplets stained for alkaline phosphatase. $\times 260$. 
NICANDER, L. (1957b) Studies in the regional histology and cytochemistry of the ductus epididymidis in stallions, rams and bulls. Acta morph. neerl.-scand. 1, 337.

Rousser, J. D. \& Stallcup, O. S. (1966) Relationship between phosphatase activity and other characteristics in bull semen. 7. Reprod. Fert. 12, 423.

Stambaugh, R. \& Buckiey, J. (1969) Identification and subcellular localization of the enzymes effecting penetration of the zona pellucida by rabbit spermatozoa. F. Reprod. Fert. 19, 423.

WisLockI, G. B. (1949) Seasonal changes in the testes, epididymis and seminal vesicles of deer investigated by histochemical methods. Endocrinology, 44, 167. 